\title{
How is the Students' Concept Understanding Ability in Terms of Three- Dimensional Visual Spatial Intelligence?
}

\author{
Dian Putri Novita Ningrum ${ }^{1}(\sqrt{)})$, Dian Aulia Citra Kusuma ${ }^{2}$ \\ ${ }^{1,2}$ Postgraduate of Mathematics Education, Faculty of Teacher Training and Education, Universitas Sebelas Maret, Surakarta, \\ Indonesia \\ Corresponding author. Email: dianputri25estudent.uns.ac.id
}

Accepted: May 25, 2021

Approved: June 30, 2021

Published: July 25, 2021

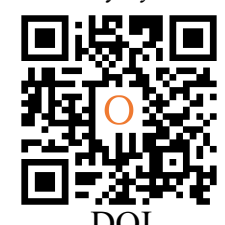

Publisher: El Syits Project
Abstract - This study aim to describe the student's concept understanding abillity in terms of spatial intelligence in three-dimensional object. It was a descriptive-qualitative research method. Collecting data by using semi-structured tests and interviews. Subject selection used purposive sampling technique, that was selecting six students with the highest Mathematics from UTS (Midle Test) scores at Texmaco Vocational School. Data analysis techniques consist of data reduction, data presentation, and drawing conclusions. Validated through triangulation. Data showed that the ability of students with high visual intelligence was better than the medium and low visual intelligence's students. Students who has low visual intelegence, have the lowest conceptual understanding ability.

Keywords - three-dimensional, mathematical concept understanding ability, spatial visual intelegence.

\section{INTRODUCTION}

Understanding concept become important thing on mathematical learning to build student's knowledge and previous understanding [1] into mathematic problem. Student's conceptual understanding, including the abilities in developing, connecting and representing information in problem solving [2], so that students who apply memorization system certain having obstacles in understanding information to solve new problems [3]. The Center for the Development and Empowerment of Educators and Educational Staff (PPPPTK) of Mathematics explained that students would understand to mathematical concepts if they met several indicators, such as: (1) presenting a concept, (2) applying a concept or algorithm, (3) providing examples and not previous examples studied concepts, (4) presenting various mathematical representations (tables, diagrams, graphs, mathematical models, etc.), (5) developing necessary and/or sufficient conditions for a concept, (6) using and selecting certain procedures, and (7) apply the concept to the problem solving [4].

Student's low ability on concepts understanding refer to the difficulties of designed question, so it is hard to know the result. Students barely answer the exam questions [5]. Therefore, that students' mathematics learning outcomes are influenced by whether or not student's concept understanding [6]. Supported data from PISA (Programme International for Student Assessment) 2018 which states that Indonesia was ranked $74^{\text {th }}$ from 79 countries. Meanwhile, with a score of 379, it is still below the OECD (Organization for Economic Co-operation and Development) average score, 489 in minimum [7]. In addition, Indonesian rank through TIMSS (Trend International Mathematics and Science Study) in 2015 was $44^{\text {th }}$ from 49 countries with an average score of 397. The data showed that Indonesian student's mathematical abilities are still low [8]. TIMSS and PISA studies got tested on four important subjects, such as: numbers, algebra, geometry, and statistics.

Geometry become one of important aspects in learning mathematics that should be understood by students because that is closely related to the context of daily life. One of the geometry materials known as three-dimensional. However, the fact showed that three-dimensional geometry was one of the most difficult materials. There were many factors causing these difficulties, for example: low aspects of student's interests, talents and intelligence. The way to offered lesson was not adapted to student's abilities, it also causes difficulties in order to mastering this concept [9].

In other side, students also have difficulties in constructing spatial structures due to the lack of imagination in visualizing the components of spatial forms [10]. There are many misunderstandings experienced by students when 
teachers explain geometric proofs that involve oral presentation of formal proofs. Therefore, based on previous research, it was concluded that learning geometry requires an approach that involves visual and multimedia tools [11].

Visual ability and their offspring included to spatial intelligence. That intelligence related to experts' theory where visual intelligence has vital role in the three-dimensional understanding. Spatial visual intelligence defined as people's ability in processing pictures, shapes, and three-dimensional space [12]. Someone who have spatial visual intelligence could imagining, conceptualizing, problem solving, and pattern finding, so they has sensitivity in balancing on color, line, shape, and space [12], [13]. Table 1 showed further information about the indicator of visual spatial intelligence theory [12].

Table. 1. Visual Spatial Intelligences Indicators of Hass Theory

\begin{tabular}{|l|l|l|}
\hline No. & Characteristic & Indicator \\
\hline 1 & Imagining & $\begin{array}{l}\text { a) Students able to use visual form to solve problem. } \\
\text { b) Students able to create idea or result of thinking process by visual form to } \\
\text { solve many problems. }\end{array}$ \\
\hline 2 & Conceptualizing & $\begin{array}{l}\text { a) Students able to mention any concepts related to the problems. } \\
\text { b) Students able to use the concepts mentioned in order to solve the problem. }\end{array}$ \\
\hline 3 & Problem solving & Students able to solve the problem correctly \\
\hline 4 & Pattern finding & Student's pattern finding refer to find point of problem to be solved. \\
\hline
\end{tabular}

Students with low visual ability prone to get misconception, as the occurrence of a discrepancy between the geometric object and the formula used [11]. While students with high spatial visual intelligence have a lot of internal imagination so they tend to be imaginative and creative [14]. It's refer to previous research which said that visual spatial intelligence refer to have high understanding on mathematical concept, while low visual intelligence refer to low understanding on mathematical concept [15]. The relationship between visual spatial intelligence and understanding of concepts about $86 \%$ [16]. Based on previous research, it only mentions the relationship between conceptual understanding and spatial visual intelligence, but it has not been described in detail how student's understanding of concepts when viewed from the visual spatial intelligence by three categories, such as high, medium, or low. In fact, each student has their own intelligence, so this could be an important reference for teachers to provide different handling to students. If this research is not carried out, there will be no development of knowledge, especially related to understanding concepts of students in correlation to visual spatial intelligence categories, at high, medium, or low.

Based on literature study and view relevant research mentioned, need a plan for further research on student's understanding of concepts in three-dimensional geometry in terms of spatial visual intelligence. This study aims to describe conceptual understanding of students viewed from spatial visual intelligence (high, medium, or low) on the subject of three-dimensional geometry. This research needs to be done as the form of literature contribution on understanding concepts in three-dimensional geometry material if viewed from visual spatial intelligence. In addition, the results of this study can be used as a basic theory for further research, for example, research on efforts to improve student's conceptual understanding skills from the level of visual-spatial intelligence on the subject of threedimensional geometry.

\section{RESEARCH METHOD}

\section{RESEARCH TYPE}

Descriptive-qualitative research was kind of this research method, where it emphasizes a complete, detailed, and in-depth description. The depiction of research data was taken from an actual condition [17].

\section{PARTICIPANTS}

The subject defined from students with different categories, as low, medium and high visual spatial intelligence. It chosen by using purposive sampling based on purpose of this study [18]. The students are $11^{\text {th }}$ grade of Texmaco Pemalang Voacational School who have learn three-dimensional geometry. Data was taken from middle test score of mathematic integrated to visual intelligence test. Two from sixty students was taken from each category to analyzed. 
Dian Putri N.N \& Dian Aulia C.K, How is the Students' Concept Understanding Ability in ...

\section{INSTRUMENTS}

This research instrument consists of (1) understanding concept test through visual spatial intelligence, and (2) interview guide used to dig up conceptual understanding in terms of visual-spatial intelligence based on student's answer sheets in more depth as a support for the test instrument. It validated by mathematic experts. Following mathematic problem occurred to figure 1 .

Lubby mendapatkan tugas dari guru matematika untuk membuat kubus dari kayu dengan panjang rusuk $8 \mathrm{~cm}$. Sebelum membuat kubus tersebut, Lubby diminta untuk memberikan nama titik - titik sudut kubus yaitu ABCD.EFGH. Kubus tersebut diberi kawat dari titik H ke garis AC. Buatlah ilustrasi kubus yang harus dibuat Lubby dan berilah nama pada tiap titik sudutnya. Kemudian, hitunglah panjang kawat yang harus dipasang Lubby di dalam kubus agar sesuai.

Fig. 1. Mathematical Problem

\section{DATA COLLECTION METHOD}

Data collecting method consist of visual spatial intelligence test, conceptual understanding, and structured interview. The test was used to dig up student's intelligence in processing picture, shape, and three-dimensional space which categorized to low, middle, or high.

Table. 2. Visual Spatial Intelligence Categories

\begin{tabular}{|l|l|}
\hline Category & Characteristic \\
\hline High & $X>57.864$ \\
\hline Middle & $30.278<X \leq 57.864$ \\
\hline Low & $X \leq 30.278$ \\
\hline
\end{tabular}

The test was essay category of three-dimensional topic. It consists of visual spatial intelligence and conceptual understanding, so it could be used to measure student's intelligence and understanding level. After obtaining students test data, it was analyzed to determine the ability to understand concepts. The analysis presented in complete, detailed, and in-depth description. To obtain these results, it was necessary to conduct interviews with students about the ability to understand mathematical concepts as supported data from the analyzed answers. Interview was the question and answer method with respondents to obtain more information as stated in [19].

\section{DATA ANALYSIS}

Data analysis consist of (1) data reduction, (2) data presentation, and (3) data conclusion. Data reduction refer to data sorting to be used in research. Then, it presented in narrative text to get conclusion. Conclusion as the last step on the research depend on previous analysis in order to answer the research question. Data validity used triangulation techniques, which obtained data come from the same source with different techniques as stated in [18].

\section{RESULT AND DISCUSSION}

The result of the test and interview among high visual spatial intelligence student (S-1) and (S-2), middle visual spatial intelligence students (S-3) and (S-4), low visual spatial intelligence students (S-5) and (S-6). It has different competence for conceptual understanding on three-dimensional topic, i.e.:

\section{CONCEPTUAL UNDERSTANDING OF VISUAL SPATIAL INTELEGENCE STUDENTS ON HIGH CATEGORY}

Student's test and interview result with high visual spatial intelligence shown by subject S-1 and S-2. Both of them come from different class, but in the same high category. Based on data and interview result, it could be known the conceptual understanding as Figure 2 bellow:

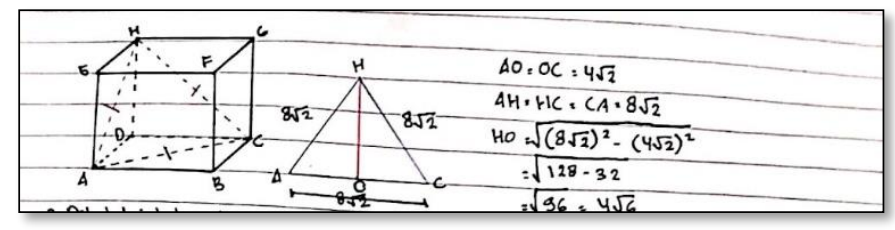

Fig. 2. S-1 Answer Sheet 
Based on Figure 1, S-1 able to re-presenting a concept by changing the story problem into the desired visualization according to the command of the question.

Based on S-1 answer on Figure 2, the student able to represent a concept by changing the questions test into visual as instruction offer. He could use their knowledge about equilateral triangle to find the actual distance from point $\mathrm{H}$ to line AC. The mathematic answers in this case give explanation with less perfect, where it written $8 \sqrt{ } 2$ without detail it come from. Hereafter in order to solve the problem, the students use Pythagoras theory. To get the detail analysis, interview was conducted as follow:

$\mathrm{P} \quad$ : "How is your understanding about the problem of the question offer?

S-1 : "in my opinion, I know about this three-dimensional test about $8 \mathrm{~cm}$. The question should be distance of point $\mathrm{H}$ to line $\mathrm{AC}$ which separate point $\mathrm{A}$ to point $\mathrm{C}$. The way I use to solve the problem by making the point of the questions. Refer to the test question, the point should be on point $\mathrm{O}$ separate to line AC. So, the question should be the distance from point $\mathrm{H}$ to point $\mathrm{O}$. Because follow the rib line $8 \mathrm{~cm}$ and line $\mathrm{AC}$ as diagonal plane. Its plane should be $8 \sqrt{2} \mathrm{~cm}$ from equation a $\sqrt{2}$."

$\mathrm{P} \quad$ : “you make a picture illustration. Do you think the illustration help you to measure distance of point $\mathrm{H}$ to $\mathrm{O}$ ?

S-1 : Illustration help me to measure the distance, because picture could illustrate the question to be easy to answer"

$\mathrm{P} \quad$ : "Based on the illustration, what kind of element from the cube that you drawing?

S-1 : "Rib element, corner point, and line length"

$\mathrm{P} \quad$ : "Based on the elements, is that any correlation each other to solve?

S-1 : "Sure, for example: line length, before dimensional shape, and space. We need to know first the rib length, and the line light. The corner point helps to illustrate the picture.

$\mathrm{P} \quad$ : "Allright, is there any obstacle when you get the question?

S-1 : "Yes, it is. If the number of the result on big categories, it is so hard to solve, just because it ends to power of number or square root.

$\mathrm{P} \quad$ :"it is true. It refers to unrealistic number, which can't be find in real live.

S-1 : "Yes. Allright."

$\mathrm{P} \quad$ : "In your opinion, is there any optional answer to solve it?

S-1 : "Yes, of course. By divided the dimensional space by two. Then, count it by root, $\sqrt{(\text { space diagonal })^{2}-}$ (diagonal shape: 2$)^{2}$. It does not need visual element, especially through

P : "By using Pythagoras theory?"

S-1 : "Yes. Because it takes a lot of time, it does not need visual elements, especially through unanswered question.

From the interview, it can be concluded that S-1 has understood what the question wants. Students know what is known and what is asked. He also explained where he got $8 \sqrt{2}$ which was not mentioned in his answer sheet, that is, it came from the diagonal of the plane. From this understanding, he concluded that if each point was drawn a line, it would form an equilateral triangle, so that all its sides were the same length. To find the distance from the point $\mathrm{H}$ to the line AC, he applied the Pythagorean theorem as a solution. Thus, the answer sheets and the results of the interviews from S-1 complement each other

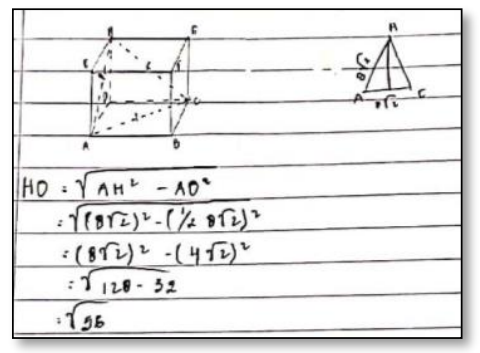

Fig. 3. S-2 Answer Sheet 
Dian Putri N.N \& Dian Aulia C.K, How is the Students' Concept Understanding Ability in ...

Based on the answer sheet S-2 in Fig.3, it can be said that S-2 is able to draw a triangle which is considered correct in the problem-solving process. S-2 writes $A C=A H=8 \sqrt{2}$ whose origin is unknown. He also used the Pythagorean formula to solve the problem and got the right answer, which is $96 \mathrm{~cm}$. As a support, interviews were conducted with masters related to understanding the following concepts.

P : "How do you understand about the question number one??"

S-2 : "From problem number one, I know that the side length of the cube is $8 \mathrm{~cm}$. Then, what is asked of the question is the distance from point $\mathrm{H}$ to line $\mathrm{AC}$ "

P : "Okay, let me try to explain how to solve the problem from what you already know and what was asked of the question."

S-2 : "The solution is by change the story problem to understand the problem. So, I changed it to the image so that it is easy to calculate it. 2 is from the formula and then forms a picture of an equilateral triangle. Then use the formula $\mathrm{AC}=\sqrt{ }(2(\mathrm{AH})-2(\mathrm{AO}))=8$ roots $2 * 2-1 / 28$ roots $2 * 2$. Then calculated and get the result $96 . "$

$\mathrm{P} \quad$ : " $\sqrt{2}$ what kind of equation you mean?"

S-2 : "Side diagonal"

P : "Mention the elements from the cube!"

S-2 : "I know that the cube has 12 rib, 6 sides, and 8 points"

$\mathrm{P} \quad$ : "Based on the elements, is that any correlation each other to solve?"

S-2 : "Yes, there is a connection. For example, a problem asks to find the distance between points AC and DE without knowing the length of the edge. Of course, it will be difficult to count. So, each element does have a relationship each other"

$\mathrm{P} \quad$ : "What a part from using this equilateral triangle, is there another way to solve it?"

S-2 : "No. I'm not try it, yet."

$\mathrm{P} \quad$ : "Okey, Allright, is there any obstacle when you get the question?"

S-2 : "No"

Based on the results of the interview, it can be said that S-2 can understand what the questions want. He can solve problems from what is known and asked on the problem using the Pythagorean formula and gets the right result, namely 96 . S-2 paints a cube on the answer sheet and then paints an equilateral triangle to make it easier to calculate. S-2 also says $8 \sqrt{2}$ is obtained from the diagonal of the plane or side so that it uses the formula $a \sqrt{2}$, where the length of the side cube. Thus, S-2 can be said that applying a concept to a problem by using one of the usual procedures.

\section{CONCEPTUAL UNDERSTANING OF VISUAL SPATIAL INTELEGENCE STUDENTS WITH MIDDLE CATEGORIES}

The results of tests and interviews with students with middle visual-spatial intelligence from S-3 and S-4. Both of them are from different classes, and have middle visual-spatial intelligence in their respective classes. Based on the data obtained and supported by the results of interviews, the ability to understand concepts in terms of middle visual spatial intelligence is as follows.

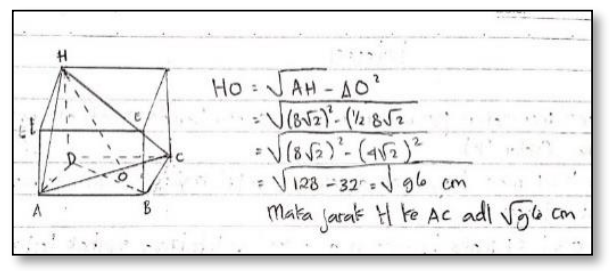

Fig. 4. S-3 Answer Sheet

Based on the answer sheet S-3 in Fig.4. S-3 is able to re-present a concept, namely by changing the story problem into the desired visualization according to the order of the question but not perfect, such as naming the corner points of a cube. Students illustrate the distance from point $\mathrm{H}$ to line $\mathrm{AC}$ and name point $\mathrm{O}$ between lines AC. From the illustration made, S-3 immediately looked for the length of $\mathrm{HO}$ without mentioning the process and immediately wrote

$\mathbf{1 3}$ | V o 1.1 ; I s s u e, 1 
$8 \sqrt{2}$ even though it was not known in the problem. He used the Pythagorean theorem and applied the concept to solve the problem of the distance from a point to a line. As a support, interviews were conducted with S-3 related to understanding the following concepts.

$\mathrm{P} \quad$ : "How is your understanding about the question?"

S-3 : "Honestly, I'm less understand about it. I just know that the equation could be used to measure distance from $\mathrm{H}$ point to line AC, so I could guess the number of line $\mathrm{HO}$.

$\mathrm{P} \quad$ : "If look at from the picture illustration, is it enough help for you?"

S-3 : "Yes. It helps enough."

P : "What do you mean?"

S-3 : "The picture does not make confuse when undertake and imagine the question"

$\mathrm{P} \quad$ : "From the illustration, is there any cube element you draw?"

S-3 : "Side, rib, corner, and diagonal"

P : "Do you understand which element you make?"

S-3 : "the lines and the corners one."

$\mathrm{P} \quad$ : "Is there any obstacle?

S-3 : "There are a lot. Sometimes easy, but more ofter does not understand."

P : :Which one you don't understand?"

S-3 : "I don't like mathematic, so make me confuse with number and word."

P : "When you visualize it into picture, do you more understand?"

S-3 : "it is enough, but my friends help so much."

P : "In your opinion, except previous manner, do you have optional way to solve the problem?"

S-3 : "Of Course, no picture will make harder to solve"

Based on the results of the interview, it can be said that S-3 can understand what the questions want. He can solve problems from what is known and asked in the problem using the Pythagorean formula and obtains the right results. However, S-3 cannot explain where $8 \sqrt{ } 2$ came from. He admitted that he only followed his friend when he was working. However, he already understands the concepts in three-dimensional geometry such as what elements are contained and he can use them to make mathematical representations. While in the application of the concept, S-3 is still confused.

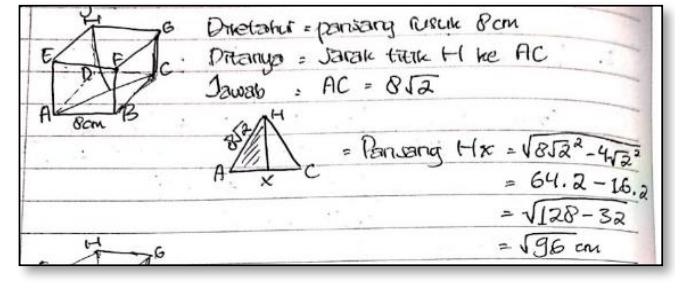

Fig. 5. S-4 Answer Sheet

Based on the S-4 answer sheet, it can be said that S-4 is able to restate a concept, namely students can change story questions into visualization of cube images, although they are not perfect like cube pictures in general. He painted lines on the sides of the cube that helped solve the problem, namely calculating the distance from point $\mathrm{H}$ to AC. The combination of the lines drawn on the cube then forms a triangle that is drawn apart from the cube. $\mathrm{S}-4$ writes $\mathrm{AC}=8 \sqrt{2}$ whose origin is unknown. He also used the Pythagorean formula to solve the problem and got the right answer, which is $96 \mathrm{~cm}$ although there is a slight correction in writing $8 \sqrt{2^{2}}-4 \sqrt{2^{2}}$ which should be $(8 \sqrt{2})^{2}-(4 \sqrt{2})^{2}$. As a support, the following excerpts from interviews with S-4 related to understanding the concept.

$\mathrm{P} \quad$ : "How is your understanding about the question?" 
Dian Putri N.N \& Dian Aulia C.K, How is the Students' Concept Understanding Ability in ...

S-4 : "My understanding limit to the text question leasoned only. Such as to find the distance of point $\mathrm{H}$ to line $\mathrm{AC}$, I will harder to answer refer to previous example given"

P : "From the question number one, what currently to be question in the statement??"

S-4 : "The rib length should be $8 \mathrm{~cm}$, also diagonal side length about $8 \sqrt{2}$ and distance of point $\mathrm{H}$ to line AC become the question offer"

P : "Try to explain me, how do you get answer about $\sqrt{ } 96 \mathrm{~cm}$ ?"

S-4 : "Because it has been known the rib length, so I have to find HX length by using Pythagoras theorem. Refer to equilateral triangle, I have to divide the rib length with 2 . After that, $8 \sqrt{2^{2}}-4 \sqrt{2^{2}}$ or $64 \times 2-$ $16 \times 2=128-32$, then we have $\sqrt{96}$ for the answer"

P : "in the case of your answer sheet, you make a picture as illustration. In your opinion, is it hep you to count the distance?"

S-4 : "The illustration really helps me. I feel easy to forget about number so I draw it"

$\mathrm{P} \quad$ : "Pay attention to triangle, where did you ger $\mathrm{AC}=8 \sqrt{ } 2$ ?"

S-4 : "From the diagonal side. If the rib length is $8 \mathrm{~cm}$, the diagonal side should be $8 \sqrt{2}$."

: "You write down the length $\mathrm{AC}=8 \sqrt{2}$. Furthermore, in the picture shows $\mathrm{AC}=\mathrm{x}$ and $\mathrm{AH}=8 \sqrt{2}$, is it true?

S-4 : "That is equilateral triangle. Distance HX should be fine, just because having equal side, so I argue that each side length $8 \sqrt{2}$ "

$\mathrm{P} \quad$ : "Oh, is that point $\mathrm{x}$ ? From the illustration what kind of element you get from the cube?"

S-4 : "Diagonal side and space, rib length, and corner point."

P : "Do you think, each element has relationship each other?"

S-4 : "Yes, they do. For example, if the rib length doesn't know, it is impossible to measure from point $\mathrm{H}$ to line AC. Even if the question is reversed before"

P : "Beside of the previous answer way have been used, is there any another way to solve?"

S-4 : "I have just known this method. I'm not find it better yet"

P : "So, is it refer to kind of previous lesson? do you get any obstacle?"

S-4 : "Yes. There is one, when I try to count $8 \sqrt{2^{2}}$, I feel confuse. I can't remember it as well"

Based on the results of the interview, it can be said that S-4 can understand what the questions want. He can solve problems using the Pythagorean formula and get the right results based on what is known and asked in the problem. S-4 also says $8 \sqrt{2}$ is obtained from the diagonal of the plane or side so that it uses the formula $a \sqrt{2}$, where $a$ is the length of the side of the cube. S-4 can be said to be able to apply a concept to the same problem, not to a new problem. He said, "I only answered as in the example given earlier", it was clear that Masters had not been able to apply a concept to a problem because he said firmly that Masters only solved problems by memorizing/procedural methods.

\section{CONCEPTUAL UNDERSTANDING OF VISUAL SPATIAL INTELEGENCE ON LOW CATEGORY STUDENTS}

The results of tests and interviews with students with low visual-spatial intelligence shown by S-5 and S- 6 . Both are from different classes, and have low visual-spatial intelligence in their respective classes. Based on the data obtained and supported by the results of interviews, the ability to understand concepts in terms of low spatial visual intelligence is as follows

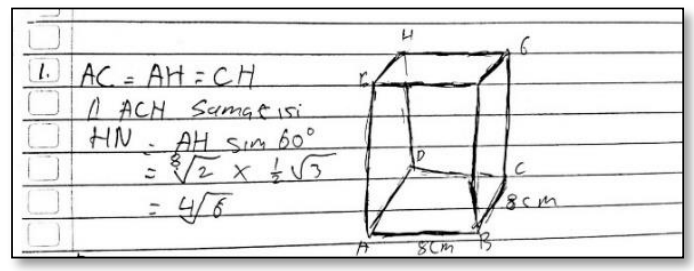

Fig. 6. S-5 Answer Sheet 
Based on the S-5 answer sheet, it can be said that S-5 has not been able to restate a concept, where students have difficulty in converting story questions into visualization and mathematical representations. From the picture of the cube made, it appears that the cube made is asymmetrical. The vertices of the cube are also not given full names. Students have difficulty illustrating the main problem where what is asked is to illustrate the distance from point $\mathrm{H}$ to line AC. In fact, on the answer sheet, $\mathrm{S}-5$ states that $A C=A H=C H$ and uses the help of trigonometry. To make it clearer, here are the results of an interview with S-5

P : "What do you understand from this question?"

S-5 : "Do you means, what I got from this material?"

$\mathrm{P} \quad$ : "Yes, from the question inside."

S-5 : "Knowing the line A to C. Only that."

P : "What is the question offer?"

S-5 : "Distance point in diagonal space. Only that."

$\mathrm{P} \quad$ : "How do you change the question to visual? Do you imagine something related?"

S-5 : "Not, at all. Honestly, I also see my friend's work"

P : "Do you mean, you don't imagine how to draw?"

S-5 : "Moreover, I draw unclear picture."

P : "Have you understand how to draw the cube refer to the question?"

S-5 : "Distance plane AC and AH."

P : "That's not the question. Furthermore, do you know the cube elements from the questions? Especially refer to your picture."

S-5 : "What is element?"

P : "Are you forget? Cube element, such point, line, and others."

S-5 : "Yes, I know"

P : "Can you mention which elements?"

S-5 : "Line, point, ABCDEFGH for the rib length A to B about $8 \mathrm{~cm}$."

$\mathrm{P} \quad$ : "Then, how do you could write $A C=A H=C H$ ?"

S-5 : "From the cube"

$\mathrm{P} \quad$ : "Where do you can imagine line AC to AH be same?"

S-5 : "The point."

P : "Where the point from?"

S-5 : "From point A outlined to point D and H"

$\mathrm{P} \quad$ : "What about point AC?"

S-5 : "From point D to C."

$\mathrm{P} \quad$ : "If your picture is true, do you think your illustration help enough? What is the reason?

S-5 : "Help to explain more. But I can draw the illustration so it is difficult to explain."

$\mathrm{P} \quad$ : "In your opinion, is there others way to answer the question?"

S-5 : "Yes, it is. If only I can draw perfectly."

Based on the results of the interview, it can be said that S-5 already understands what the questions want, but cannot make a mathematical representation. Even though he has done procedurally and brought up $A C=A H=C H$, he is confused about it and must be provoked first. He has difficulty in applying the concept of three-dimensional geometry, and regrets that his drawings are still not good. He also admitted that the calculations he made were obtained from looking at other friends' answers. 


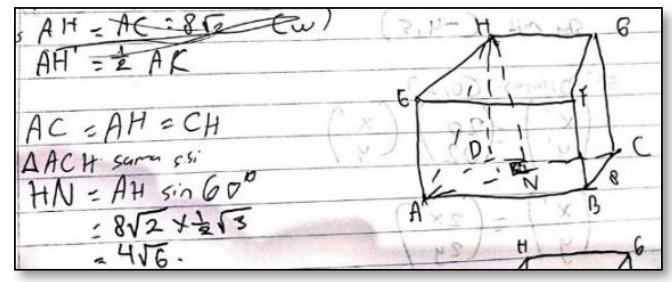

Fig. 7. S-6 Answer Sheet

Based on the answer sheet S-6 in Fig. 7, S-6 tries to paint a cube by naming the corner points. In addition to naming the vertices of the cube, S-6 also paints the lines HA, HN, and AC with dotted lines. Then, S- 6 writes $A C=A H=C H$ and the triangle $A C H$ is equilateral. Based on the answer sheet, S-6 answered according to what was asked of the question, namely determining the distance from $\mathrm{H}$ to the AC line and getting the correct result, namely $4 \sqrt{6}$. S- 6 uses trigonometry to solve it. However, S-6 is considered not to have an understanding of the concept of three-dimensional material because the answers written on the answer sheet are not the result of their own completion. The following are the results of interviews with S-6 related to understanding the concept.

P : "By looking the question, what do you understand?"

S-6 : "I do apologize, I cheat to my friend."

$\mathrm{P} \quad$ : "What is your reason by cheating that?"

S-6 : "I don’t understand, yet."

$\mathrm{P} \quad$ : "Before you try to cheat, do you how the cube shape is?"

S-6 : "Yes. Cube just like a rectangle"

$\mathrm{P} \quad$ : "Okey. So, it means have a same length, is it right?

S-6 : "Yes, it has same length."

$\mathrm{P} \quad$ : "In your opinion, the picture does not match the actual picture of the cube?"

S-6 : "The picture a little too long. So, it's not exactly like a cube in general."

P : "Well, you already know what the shape of the cube looks like, right? So, what are the cube elements?

S-6 : "I don't understand."

P : "How about labeling the corner points of a cube?"

S-6 : "Points A, B, C, D must be on one side, ma'am. Likewise, points E, F, G, H must be on one side."

P : "From what you wrote on the answer sheet, what do you understand?"

S-6 : "Every corner of a cube has a vertex."

P : "What is the others?"

S-6 : "A cube has all sides flat and all sides are the same length."

$\mathrm{p} \quad$ : "What about the calculation problem? That's what you're looking for point $\mathrm{DH}$ or $\mathrm{OH}$ ?

S-6 : "I don't understand the calculation. DH point."

P : "Have you ever heard or read about side diagonals and room diagonals?"

S-6 : "Not, yet."

$P \quad$ : “a) Space diagonal b) Side diagonal c) Edge d) Corner point. Well, try to answer according to the four options, yes. 1) What is A, B, C, D, E, F, G, H called? 2) AB, BC, CD what are they called? 3) AF, EB what are they called? 4) What is HB, AG called?"

S-6 : “1) corner point, 2) space diagonal, 3) side diagonal, 4) corner point. If I'm not wrong” 
Based on the results of the interview, it can be said that S-6 cannot understand what the questions want. He can solve problems using the help of trigonometry and get the right results but he admits that he is not the result of his own work. He said, "The picture is still a bit long, ma'am, so it's not exactly like a cube in general", it was clear that S-6 had knowledge of the shape of a cube and realized that it was still not accurate to paint a cube on the answer sheet. S-6 cannot identify any elements contained in the cube.

\section{DISCUSSION}

Based on the results of tests and interviews in terms of visual-spatial abilities with high (S-1 and S-2), middle (S3 and S-4), and low (S-5 and S-6) categories, each category has an ability to understand different concepts. In the high-spatial visual category, S-1 and S-2 were able to provide visualization of the cube requested by the question. Both draw the cube ABCD.EFGH exactly. After that, they made an auxiliary line connecting point $\mathrm{H}$ to the AC line which had been connected using a dotted line. In accordance with the concept of three-dimensional geometry at the distance of the point to the line, the point must be made perpendicular to the line. In this case, the student draws a line from point $\mathrm{H}$ and is perpendicular to the line AC. This proves that students are able to present a mathematical representation in the form of a cube image. From the figure, S-1 and S-2 make a guide line so as to form a triangle HAC. The two students were also able to explain that the triangle HAC is an equilateral triangle because the three lines that form the triangle are diagonals of the sides or planes of the cube ABCD.EFGH. That is, students are able to use and choose certain procedures that link the diagonal side of the cube to the equilateral triangle that has been made. S-1 can mention that there are other ways that can be used to solve the problem. Thus, it is in line with the research results that they can imagine the transformation of objects so that they have the ability to see from different angles [20]. In the application of the concept as problem solving, S-1 and S-2 apply the concept of the Pythagorean theorem as problem solving. Both of them calculated the distance from point $\mathrm{H}$ to line $\mathrm{AC}$ and got $96 \mathrm{~cm}$ as the answer. In line with the research results that students who have high visual intelligence have good abilities in solving mathematical problems [21]. It can be said that subjects with high visual-spatial intelligence category meet all indicators of concept understanding in this study.

In the medium visual-spatial category, S-3 and S-4 are able to change story problems into the desired visualization although it is not perfect, such as naming the corner points of the cube and the shape of the cube which is not like a cube in general. S-3 and S-4 have also made a connecting line from point $\mathrm{H}$ to line AC to help solve the problem. In accordance with the concept of three-dimensional geometry at the distance of the point to the line, the point must be made perpendicular to the line. S-3 presents an illustration of a cube at once with a triangular shape in the cube, while S-4 presents an image of a separate triangle with a cube to make it easier to solve. It can be said that S-3 and S-4 are able to present mathematical representations. S-3 and S-4 have written and explained the solution using the Pythagorean theorem to solve the problem of the distance from a point to a line. That way, they can be said to be able to choose and use certain procedures and get the right final result even though there are still a few mistakes in writing. For example, S-4 wrote $\sqrt{ }\left(8 \sqrt{2}^{2}-4 \sqrt{2^{2}}\right)$, which should be $\left.\sqrt{ }(8 \sqrt{2})^{2}-(4 \sqrt{2})^{2}\right)$ on the answer sheet. S-3 dan S-4 have not been able to apply the concept to a problem because they can only solve problems by rote/procedural methods. This is in line with the results of research that students are certain to have obstacles in understanding information if students apply rote/procedural in solving new problems [3], because understanding the concept includes the ability to develop, relate, and represent information in problem solving [2].

Meanwhile, in the low visual-spatial category, namely S-5 and S-6, in addition to students having difficulty in making cube images, students are also confused in applying the concept as a whole. Based on the interview, S-5 answered with confusion and had to be directed. These doubts can be caused by several factors, for example the subject has difficulty in dealing with new problems [22] or students are accustomed to solving procedural problems [23]. On the other hand, S-6 admitted that he saw the answers of other students and did not understand the material even though it had been taught by the teacher. This can be one of the causes of difficulties in learning three-dimensional geometry from external factors where there is a mismatch of the methods used by teachers when teaching [9].

In addition, S-5 is less precise in answering the information contained in the questions. In the interview, he replied that what he knew was the line $\mathrm{A}$ to $\mathrm{C}$, but did not mention the fact that the known edge length was $8 \mathrm{~cm}$. The visualization of the cube image made by S-5 is also not appropriate, where the sides on the base of the cube have misaligned lines, the naming of the corner points on the cube is also incomplete. The command to illustrate the distance from point $\mathrm{H}$ to AC was not made by S-5. Correspondingly, S-6 also draws a cube with an irregular shape. However, he made a guide line to connect the distance from point $\mathrm{H}$ to line AC. Spatial intelligence is the ability to see from different angles [20]. Most of the mistakes made by students with low spatial intelligence are because they cannot imagine and solve problems in geometry questions well.

This continues in the ability to present mathematical representations. After being guided, S-5 can explain where the $A C=A H=C H$ came from which he wrote on the answer sheet when previously he did not understand at all. The 
Dian Putri N.N \& Dian Aulia C.K, How is the Students' Concept Understanding Ability in ...

same thing happened to S-6, which was already confused from making the cube illustration. It was only after S-6 was directed about the elements that make up a cube, S-6 began to understand a little about how to illustrate it. Thus, it can be said that they have not been able to present a mathematical representation. In fact, to achieve a meaningful understanding of mathematics in classroom learning, it is mandatory to assume that representation is a supporting argument [24].

Furthermore, from the description of the answer sheet, it can be seen that S-5 and S-6 use the same concept in problem solving, namely using trigonometry on triangles derived from cubes. However, when both were asked about the origin of trigonometry sin 60, both S-5 and S-6 did not answer. Thus, it can be said that research subjects with low visual-spatial categories tend to make more mistakes so they cannot imagine and solve three-dimensional geometry problems properly. Students with low spatial intelligence made more mistakes than students with middle or high spatial intelligence. Low spatial ability causes students to make more errors in solving geometry problems, especially types of transformation errors, process skills errors, and coding errors. [25]. In students with middle and low visual spatial abilities, this can happen because students are not able to transform skills and there is a lack of understanding in choosing the procedures to be used in problem solving. [26]. Thus, students do not meet the indicators in using and choosing certain procedures, as well as applying concepts to a problem solving.

\section{CONCLUSION}

Based on the explanation that has been discussed in the discussion, it appears that the understanding of concepts in high, medium, and low visual spatial intelligence has significant differences. In students with high spatial visual intelligence, students are able to present concepts, present mathematical representations, choose the procedures used, and apply understanding concepts in problem solving. Meanwhile, students with middle visual-spatial intelligence have problems choosing certain procedures in solving problems and their application in solving problems. Finally, students with low visual-spatial intelligence have difficulty in many ways. The difficulty of presenting mathematical representations, choosing certain procedures, and applying concepts to problem solving. In summary, this states that students with high visual spatial intelligence categories have better conceptual understanding abilities than students with medium and low visual spatial intelligence. While students with middle visual-spatial intelligence have better conceptual understanding skills than students with low-visual-spatial intelligence. Based on the findings that have been obtained from this study, the authors can provide suggestions for further researchers to conduct research related to efforts to overcome students' problems in understanding concepts, especially in terms of students' visual spatial intelligence. Teachers can also provide different learning methods because each student has different abilities.

\section{REFERENCES}

[1] N. R. Council and M. L. S. Committee, Adding It Up: Helping Children Learn Mathematics. Washington, DC: The National Academies Press, 2001.

[2] D. Salim Nahdi and M. Gilar Jatisunda, "Conceptual Understanding And Procedural Knowledge: A Case Study on Learning Mathematics of Fractional Material in Elementary School,” J. Phys. Conf. Ser., vol. 1477, no. 4, p. 042037, Mar. 2020, doi: 10.1088/1742-6596/1477/4/042037.

[3] E. Fennema and T. A. Romberg, Mathematics Classrooms That Promote Understanding. New York: Routledge, 1999.

[4] S. Wardhani, "Analisis SI dan SKL Mata Pelajaran Matematika SMP/MTS Untuk Optimalisasi Pencapaian Tujuan,” Pus. Pengemb. dan Pemberdaya. Pendidik dan Tenaga Kependidikan Mat., pp. 9-10, 2008.

[5] K. Luneta, "Understanding students' misconceptions: An analysis of final grade 12 examination questions in geometry," Pythagoras, vol. 36, no. 1, pp. 1-11, 2015, doi: 10.4102/pythagoras.v36i1.261.

[6] L. dan L. Novitasari, "Pengaruh Kemampuan Pemahaman Konsep Matematika terhadap Hasil Belajar Matematika," Pros. Disk. Panel Nas. Pendidik. Mat. Fak. Tek. Mat. dan Ilmu Pengetah. Alam Univ. Indraprasta PGRI., pp. 758-766, 2017.

[7] OECD, "What Students Know and Can Do," in PISA 2009 at a Glance, vol. I, 2019.

[8] H. Prastyo, "Kemampuan Matematika Siswa Indonesia Berdasarkan TIMSS," J. Padegogik, vol. 3, no. 2, pp. 111-117, 2020, [Online]. Available: https://doi.org/10.35974/jpd.v3i2.2367.

[9] R. Novita, R. C. I. Prahmana, N. Fajri, and M. Putra, "Penyebab kesulitan belajar geometri dimensi tiga," J. Ris. Pendidik. Mat., vol. 5, no. 1, p. 18, 2018, doi: 10.21831/jrpm.v5i1.16836.

[10] D. S. Parangin-angin and ..., "Analisis Kemampuan Spasial Visualization Siswa Pada Materi Geometri Transformasi Menggunakan Aplikasi Zoom Di Sma Persiapan ...," ... J. Ilm. Pendidik. ..., vol. 8, no. 2, pp. 389-398, 2021, [Online]. Available: https://www.ejournal.stkipbbm.ac.id/index.php/mtk/article/view/759.

[11] S. Jelatu, K. Mandur, R. Jundu, and Y. Kurniawan, "Relasi Antara Visualisasi Spasial Dan Orientasi Spasial Terhadap Pemahaman Konsep Geometri Ruang," Joornal Songke Math, vol. 1, no. 1, pp. 47-59, 2018, [Online]. Available:

19|V o l. 1; I s s u e, 1 
Ordinal: Innovation in Research, Development, and Learning on Mathematics Education Journal

http://ejournal.stkipsantupaulus.ac.id/index.php/jsm\%0ARELASI.

[12] A. Syafiqah, "Deskripsi Kecerdasan Visual Spasial Siswa dalam Memecahkan Masalah Bangun Ruang Sisi Datar Ditinjau Berdasarkan Tingkat Kemampuan Awal Geometri pada Siswa Kelas VII SMP,” vol. 4, no. 1, pp. 68-82, 2020.

[13] S. Rimbatmojo, T. A. Kusmayadi, and R. Riyadi, "Metacognition Difficulty of Students with Visual-Spatial Intelligence during Solving Open-Ended Problem,” J. Phys. Conf. Ser., vol. 895, no. 1, 2017, doi: 10.1088/1742-6596/895/1/012034.

[14] Y. Setiani, "Pengaruh Tingkat Kecerdasan Visual-Spasial terhadap Literasi Kuantitatif Mahasiswa Calon Guru Matematika," Kreano J. Mat. Kreat., vol. 9, no. 1, pp. 38-46, 2018, doi: 10.15294/kreano.v9i1.12258.g7946.

[15] A. Ani, M. Maulana, and C. Sunaengsih, "Pengaruh Pendekatan Kontekstual Berbasis Kecerdasan Visual-Spasial Terhadap Kemampuan Pemahaman Matematis Siswa Sekolah Dasar," Pengaruh Pendekatan Kontekst. Berbas. Kecerdasan Vis. Terhadap Kemamp. Pemahaman Mat. Siswa Sekol. Dasar, vol. 2, no. 1, pp. 971-980, 2017, doi: 10.17509/jpi.v2i1.11234.

[16] M. Zaiyar, I. Rusmar, and T. Yuniarti, "Correlation between Students' Mathematical and Logical Spatial Intelligence in Terms of Understanding Concepts," Malikussaleh J. Math. Learn., vol. 3, no. 2, p. 76, 2020, doi: 10.29103/mjml.v3i2.3005.

[17] F. Nugrahani, Metode Penelitian Kualitatif dalam Penelitian Pendidikan Bahasa. Surakarta: Cakra Books, 2014.

[18] Sugiyono, Metode Penelitian Kuantitatif Kualitatif dan R \& D. Bandung: Alfabeta, 2018.

[19] S. Arikunto, Dasar-Dasar Evaluasi Pendidikan Edisi 3, 3rd ed. Jakarta: PT Bumi Aksara, 2021.

[20] P. J and I. B, Mental imagery in the child. New York: Basic Books, 1971.

[21] J. Eliot, Models of psychological space: Psychometric, developmental, and experimental approaches. Springer Science \& Business Media, 2012.

[22] M. N. Kholid, C. Sa'dijah, E. Hidayanto, and H. Permadi, "How are students' reflective thinking for problem solving?," J. Educ. Gift. Young Sci., vol. 8, no. 3, pp. 1135-1146, 2020, doi: 10.17478/JEGYS.688210.

[23] M. N. Kholid, A. Imawati, A. Swastika, S. Maharani, and L. N. Pradana, "How are Students' Conceptual Understanding for Solving Mathematical Problem?," J. Phys. Conf. Ser., vol. 1776, no. 1, p. 012018, 2021, doi: 10.1088/17426596/1776/1/012018.

[24] S. J. Pape and M. A. Tchoshanov, "The Role of Representation(s) in Developing Mathematical Understanding," Theory Pract., vol. 40, no. 2, pp. 118-127, May 2001, doi: 10.1207/s15430421tip4002_6.

[25] N. Riastuti, M. Mardiyana, and I. Pramudya, "Students' errors in geometry viewed from spatial intelligence," in Journal of Physics: Conference Series, 2017, vol. 895, no. 1, p. 12029.

[26] K. F. Zamzam and F. A. Patricia, "Error analysis of newman to solve the geometry problem in terms of cognitive style," Adv. Soc. Sci. Educ. Humanit. Res., vol. 160, pp. 24-27, 2018.

[1] Budiman, R. (2013). Utilizing Skype for providing learning support for Indonesian distance learning students: A lesson learnt. Procedia - Social and Behavioral Sciences, 83: 5-10

[2] Chandrasena Premawardhena, N., ICT in the foreign language classroom in Sri Lanka: A journey through a decade. $10^{\text {th }}$ World Conference on Computers in Education (WCCE 2013), Nicolaus Copernicus University, July 2-5 2013, Torun, Poland.pp 223224

[3] Chandrasena. Premawardhena, N. (2012). Introducing Computer Aided Language Learning to Sri Lankan Schools: Challenges and Perspectives. $15^{\text {th }}$ International Conference on Interactive Collaborative Learning and $41^{\text {st }}$ International Conference on Engineering Pedagogy (ICL \& IGIP), Villach, Austria.

\section{AUTHORS}

Dian Putri Novita Ningrum is a master's student of Mathematics Education at Sebelas Maret University, Surakarta, Indonesia (email: dianputri25@student.uns.ac.id).

Dian Aulia Citra Kusuma is a a master's student of Mathematics Education at Sebelas Maret University, Surakarta, Indonesia (email: dianauliack@ student.uns.ac.id). 